Malaysian Journal of Social Sciences and Humanities (MJSSH), Volume 6, Issue 12, (page 1 - 12), 2021

DOI: https://doi.org/10.47405/mjssh.v6i12.1202

\begin{tabular}{|c|c|}
\hline & Malaysian Journal of Social Sciences and Humanities (MJSSH) \\
\hline Malaysian Journal of & Volume 6, Issue 12, December 2021 \\
\hline (MJ. SSH) & e-ISSN : 2504-8562 \\
\hline & $\begin{array}{l}\text { Journal home page: } \\
\text { www.msocialsciences.com }\end{array}$ \\
\hline
\end{tabular}

\title{
Pengetahuan, Sikap dan Amalan Tentang Covid-19 dalam kalangan Pelajar Sekolah Berasrama Penuh di Malaysia
}

\author{
Farah Najihah Omar' ${ }^{1}$, Shahlan Surat ${ }^{1}$ \\ 1Fakulti Pendidikan, Universiti Kebangsaan Malaysia (UKM), Malaysia \\ Correspondence: Farah Najihah Omar (p104002@siswa.ukm.edu.my)
}

\begin{abstract}
Abstrak
Coronavirus 2019 atau lebih dikenali dengan Covid-19 merupakan satu pandemik yang telah mengakibatkan angka kematian yang cukup tinggi di seluruh pelosok dunia. Berikutan peningkatan kes yang mendadak di Malaysia khususnya, kerajaan telah melaksanakan Perintah Kawalan Pergerakan (PKP) bermula pada 18 Mac 2019 sehingga kini. Justeru, kajian ini bertujuan untuk mengenal pasti tahap pengetahuan, sikap dan amalan tentang Covid-19 di kalangan pelajar Sekolah Berasrama Penuh. Selain itu, objektif kajian ini juga bagi mengenal pasti hubungan antara pengetahuan, sikap dan amalan tentang Covid-19 di kalangan pelajar Sekolah Berasrama Penuh. Kajian yang dijalankan menggunakan kaedah tinjauan keratan rentas ke atas 365 orang pelajar di Sekolah Menengah Agama Persekutuan Kajang Selangor, Sekolah Berasrama Penuh Integrasi Rawang dan Sekolah Berasrama Penuh Integrasi Gombak, Selangor dimana pelajar perempuan terdiri daripada $54.2 \%$ dan pelajar lelaki sebanyak 45.8\%. Data diperoleh melalui soal selidik yang diedarkan dikumpulkan dan dianalisis menggunakan Statistical Package for the Social Science. Dapatan kajian menunjukkan tahap pengetahuan tentang Covid-19 dalam kalangan pelajar Sekolah Berasrama Penuh adalah berada pada tahap yang sederhana $[\mathrm{min}=4.63, \mathrm{sp}=0.926]$ manakala skor tahap sikap pada tahap yang tinggi $[\mathrm{min}=4.17, \mathrm{sp}=0.462]$ diikuti dengan tahap amalan juga pada tahap tinggi [ $\min =4.31$, $\mathrm{sp}=0.508]$. Hasil analisis korelasi pula menunjukkan tidak terdapat hubungan yang signifikan antara pengetahuan dengan sikap $[\mathrm{r}=.033$, $\mathrm{p}>$.554], manakala hubungan pengetahuan dengan amalan menunjukkan hubungan yang signifikan $[\mathrm{r}$ $=0.196, \mathrm{p}<0.05]$. Dapatan kajian juga menunjukkan adanya hubungan sikap dan amalan secara signifikan [ $\mathrm{r}=0.389, \mathrm{p}<0.05]$ tentang Covid-19 dalam kalangan pelajar Sekolah Berasrama Penuh. Berdasarkan dapatan kajian, dapat disimpulkan bahawa amalan yang rendah dipengaruhi oleh sikap pelajar tersebut mengenai penjagaan kesihatan untuk menghindarkan jangkitan Covid-19. Hal ini kerana sikap ada hubungan yang positif terhadap amalan. Oleh itu untuk meningkatkan amalan pelajar ke tahap yang tinggi perlu mengubah sikap dan pengetahuan pelajar terlebih dahulu.
\end{abstract}

Kata kunci: pengetahuan, sikap, amalan, Covid-19, pelajar sekolah berasrama

\section{Knowledge, Attitude and Practices Regarding Covid-19 Among Malaysian Boarding School Students}

\begin{abstract}
Coronavirus 2019, better known as Covid-19, has caused a global pandemic and a high death rate worldwide. Following the sharp increase of Covid-19 cases in Malaysia, the government has enforced Movement Control Order (PKP) starting 18 March 2020, which has continued until now. This study aims to identify the level of knowledge, attitudes and practices regarding Covid-19 among Students in
\end{abstract}


full boarding schools. This study also examined the relationship between knowledge, attitude and practices regarding Covid-19 among students in full boarding schools. The study was conducted using the cross-sectional survey method. It involved 365 students from Sekolah Menengah Agama Persekutuan Kajang (SMAP Kajang), Sekolah Berasrama Penuh Integrasi Rawang (SBPI Rawang) and Sekolah Berasrama Penuh Integrasi Gombak (SBPI Gombak) In terms of gender, the respondents comprised $54.2 \%$ female students and $45.8 \%$ male students. Data were collected through questionnaires and were analysed using the Statistical Package for the Social Science. The study's findings showed that students in these three full boarding schools have moderate knowledge about Covid-19 among [mean $=4.63$, sd $=0.926$ ] while their attitude and practice is high with a mean of 4.17 , sd $=0.462$ and 4.31 , sd $=0.508$, respectively. The results of correlation analysis indicate that there is no significant relationship between knowledge and attitude $[\mathrm{r}=.033, \mathrm{p}>.554]$. Meanwhile, the study found a significant relationship between knowledge and practice $[\mathrm{r}=0.196, \mathrm{p}<0.05]$ and between attitude and practice $[\mathrm{r}=0.389, \mathrm{p}<0.05]$ regarding Covid-19 among students in full boarding schools. This study concluded that students' practice regarding Covid-19 is influenced by their attitude about health care to curb COVID-19 infection. In this case, attitude has a positive relationship with practice. Therefore, changing their attitude and increasing the students' knowledge are necessary to improve their practices regarding Covid-19.

Keywords: knowledge, attitude, practices, Covid-19, students in boarding schools

\section{Pengenalan}

Pada akhir Disember 2019, satu virus baru telah ditemui yang menyebabkan penyakit 'Coronavirus Disease' iaitu yang boleh mengakibatkan jangkitan pada saluran pernafasan. Setelah lebih 8 bulan, wabak yang berasal dari negara China itu telah merebak ke seluruh dunia dan menjangkiti lebih 19 juta orang dan menyebabkan lebih 700,000 kematian (WHO, 2020). Di Malaysia, gelombang pertama Covid-19 berlaku pada Februari 2020, diikuti gelombang kedua pada awal bulan Mac. Berikutan peningkatan kes, Perintah Kawalan Pergerakan (PKP) telah dilaksanakan oleh kerajaan iaitu bermula pada 18 Mac 2020 (Jaafar \& Azzeri, 2020). Di samping memberi rawatan kepada pesakit, Kementerian Kesihatan Malaysia juga aktif memberikan peringatan dan menyampaikan informasi terkini berkenaan Covid-19. Satu kajian yang dijalankan pada Mac 2020 mendapati bahawa tahap pengetahuan, sikap dan amalan golongan dewasa di Malaysia berkenaan Covid-19 adalah melebihi $80 \%$ (Hamed et al., 2020). Pandemik yang meragut nyawa ini juga turut memberi impak kepada proses pengajaran dan pembelajaran (PdP) dimana proses pembelajaran secara bersemuka, face to face yang selama ini dijalankan perlu diberhentikan susulan pengumuman pelaksanaan Perintah Kawalan Pergerakan (PKP) oleh Perdana Menteri Malaysia, Tan Sri Dato' Haji Mahiaddin bin Md. Yasin. Bertitik tolak daripada hal ini, para pendidik dan tenaga pengajar di sekolah-sekolah mahupun di institusi-institusi pengajian tinggi (IPT) telah menukar platform pengajaran ke kelas secara atas talian bagi memastikan pelajar-pelajar tidak ketinggalan dengan sesi pembelajaran disebabkan oleh norma baru iaitu pembelajaran dalam talian atau lebih dikenali dengan online learning. Walau bagaimanapun, terdapat beberapa isu yang timbul apabila pengajaran secara atas talian ini diaplikasikan. Antara isu yang melibatkan dua-dua pihak ialah capaian internet (Nawar, 2021). Sepanjang tempoh PKP, sekolah dan asrama ditutup sepenuhnya dan pelajar-pelajar sekolah 'terpaksa' terus tinggal di rumah dan menjalankan aktiviti di dalam rumah sahaja. Segala informasi mengenai Covid-19 sangat mudah diperoleh melalui televisyen, media sosial dan media cetak. Namun tidak diketahui adakah maklumatmaklumat tersebut sahih dan difahami oleh pelajar-pelajar. Malah satu kajian mendapati bahawa, walaupun pengetahuan orang awam amat memuaskan, tetapi majoriti responden melaporkan bahawa mereka memperoleh sangat banyak informasi yang diragui kesahihannya (Jaafar \& Azzeri et al., 2020).

Kerajaan mengumumkan pembukaan sekolah secara berperingkat bermula 25 Julai 2020. Sekolah berasrama dibenarkan beroperasi bermula 3 Ogos 2020. Cabaran sebenar bermula kepada para pelajar untuk menjalani kehidupan sebenar pada era pandemik Covid-19. Kehidupan di asrama tanpa pemantauan ibu bapa berkemungkinan menyebabkan pelajar lalai atau kurang peka dengan penyakit 
berjangkit ini. Pemahaman yang jelas tentang Covid-19 dan langkah pencegahan adalah sangat penting supaya jangkitan dapat dielakkan. Justeru, kami berhasrat untuk melakukan satu kajian untuk mengenal pasti perbezaan pengetahuan, sikap dan amalan tentang Covid-19 antara pelajar lelaki dan perempuan di Sekolah Berasrama Penuh dan mengenal pasti hubungan antara pengetahuan, sikap dan amalan tentang Covid-19 di kalangan pelajar Sekolah Berasrama Penuh. Dapatan kajian ini dapat membantu pihak kementerian dan sekolah untuk merancang program berkaitan demi memastikan kesihatan dan kesejahteraan pelajar-pelajar sekolah asrama penuh khususnya, dan pelajar-pelajar lain amnya. Oleh itu, kajian dijalankan bagi tujuan mengenal pasti tahap pengetahuan, sikap dan amalan tentang Covid-19 di kalangan pelajar Sekolah Berasrama Penuh dan mengenal pasti hubungan antara pengetahuan, sikap dan amalan tentang Covid-19 di kalangan pelajar Sekolah Berasrama Penuh.

\section{Sorotan Literatur}

\section{Pengetahuan}

Menurut Listiani (2015), pengetahuan merujuk kepada pancaindera seseorang seperti penglihatan, pendengaran, rasa, sentuhan dan sebagainya yang menjurus kepada penghasilan pengetahuan. Sebahagian pengetahuan manusia diperoleh melalui mata dan telinga. Setiap orang mempunyai tingkat pengetahuan yang berbeza-beza. Antara elemen dalam pengetahuan iaitu memahami (comprehension), analisis (analysis), sintesis (synthesis), aplikasi (application) dan evaluasi (evaluation) (Listiani 2015). Seseorang yang berwawasan mempunyai pengetahuan (knowledge) yang lebih komprehensif dan luas. Kajian yang dijalankan oleh Balvir et al. (2021) ke atas 7978 peserta kajian termasuk 3289 pelajar sekolah menengah di India mendapati bahawa seramai $83.3 \%$ daripada mereka mempunyai tahap pengetahuan yang tinggi berkenaan Covid-19. Menurut kajian Gebredsadik et al. (2021) terhadap 546 pelajar dari Universiti Debre Berhan di Ethiopia mendapati bahawa peratusan pelajar yang mempunyai pengetahuan tentang Covid-19 adalah pada tahap yang tinggi dengan $71.4 \%$, dimana para pelajar tersebut mempunyai pengetahuan berkenaan simptom-simptom yang dialami oleh pesakit yang dijangkiti oleh Covid-19.

Kajian oleh Umeizudike e al. (2020) terhadap sekumpulan pelajar di salah sebuah universiti di Fakulti Pergigian di Nigeria mendapati bahawa pelajar-pelajar di fakulti itu mempunyai tahap pengetahuan yang tinggi tentang pandemik ini dan peserta-peserta kajian ini turut mengambil langkah pencegahan bagi menghentikan penularan Covid-19 di Nigeria dengan mengamalkan langkah-langkah pencegahan yang efektif. Selain daripada itu, kajian Muhammad (2020), ke atas seramai 2034 pelajar dari universiti awam dan swasta di Jordan mendapati seramai 56.6\% mempunyai tahap pengetahuan yang tinggi manakala seramai $40.5 \%$ mempunyai tahap pengetahuan yang sederhana.

Kesimpulannya, hasil daripada beberapa kajian mendapati tahap pengetahuan pelajar adalah pada tahap tinggi. Dalam konteks kajian ini, pengetahuan merujuk kepada tahap pengetahuan pelajar sekolah berasrama penuh berkenaan Covid-19. Oleh itu, kajian ini bukan sahaja mengenal pasti tahap sikap dan amalan pelajar tentang Covid-19 tetapi turut mengenal pasti tahap pengetahuan pelajar berasrama penuh.

\section{Sikap}

Menurut Rajaratenam (2014), sikap merupakan reaksi atau respons yang tidak dapat dilihat tetapi hanya dapat ditafsirkan dahulu dari perilaku seseorang. Rajarenam (2014) berpendapat penstrukturan sikap boleh dibahagikan kepada 3 iaitu, kognitif, afektif dan tingkah laku. Walau bagaimanapun, pengalaman peribadi, pengaruh kebudayaan, media massa, agama dan emosi merupakan antara faktor yang mempengaruhi sikap. Kajian yang dijalankan oleh Hamed et al. (2020) mendapati bahawa, sikap pelajar di Bangladesh terhadap Covid-19 berada pada tahap yang tinggi. Hal ini demikian kerana, pelajar-pelajar ini turut mempunyai disiplin yang tinggi bagi mengekang penularan Covid-19 ini. Bertitik tolak daripada perkara ini, seramai $62.3 \%$ pelajar mempunyai sikap yang positif bagi memastikan penularan Covid-19 dapat dihentikan di Jordan dan di universiti mereka khususnya. 
Kajian Chen (2020) di Wilayah Anhui mendapati majoriti penduduk di Wilayah tersebut iaitu sebanyak $97.5 \%$ daripada 4016 peserta kajian mempunyai tahap sikap yang positif terhadap pencegahan Covid-19. Hal ini disokong oleh kajian Asraf (2020) yang mendapati $96.4 \%$ responden mempunyai sikap yang positif terhadap pandemik ini. Kajian oleh Nimetcan (2021) mendapati bahawa sikap pelajar di sebuah institusi pengajian di Turki menunjukkan sikap yang positif. Hal ini demikian kerana, para pelajar tersebut mempunyai tahap keyakinan yang tinggi bagi mengekang Covid-19 daripada terus menular.

Kesimpulannya, kajian-kajian lepas menunjukkan bahawa majoriti responden menunjukkan sikap yang positif terhadap pencegahan Covid-19. Perkara ini dapat dibuktikan dengan terdapat juga 90\% responden yang menunjukkan sikap yang positif dalam mengekang penularan wabak ini. Justeru, kajian ini juga melihat kepada tahap sikap pelajar sekolah berasrama penuh di Malaysia tentang Covid-19.

\section{Amalan}

Menurut Ressa (2020), amalan merujuk kepada tindakan dan perlakuan seseorang individu secara berulang kali atau secara rutin sehingga menjadi satu kebiasaan buat individu berkenaan. Amalan yang dibincangkan dalam kajian tertumpu kepada amalan yang dilaksanakan oleh pelajar sekolah berasrama penuh dalam mengekang penularan Covid-19 ini. Berbeza pula dengan kajian oleh Al-Hanawi (2020) dimana seramai $91.4 \%$ peserta kajian mempunyai amalan yang tinggi dalam memastikan keselamatan dan kesihatan terjamin. Hasil kajian mendapati majoriti peserta kajian melakukan amalan seperti tidak berkunjung ke tempat yang sesak, sentiasa memakai pelitup muka, mencuci tangan dan sentiasa menjaga jarak antara satu sama lain (Al-Hanawi, 2020).

Hasil kajian mendapati peratusan wanita iaitu sebanyak $97.1 \%$ yang mengambil langkah-langkah pencegahan yang efektif lebih tinggi berbanding lelaki (Balvir, 2021). Muhammad (2020) pula dalam kajian yang dijalankan terhadap 389 orang pelajar di salah sebuah sekolah di Indonesia mendapati mereka mempunyai amalan yang kurang terhadap langkah-langkah pencegahan Covid-19. Minjung (2021) menyatakan pengetahuan, sikap dan amalan berkait rapat kerana jika pengetahuan seseorang berkenaan Covid-19 tinggi, maka, sikap dan amalan juga akan turut setanding.

Kesimpulannya, kajian ini juga mendapati majoriti responden melakukan amalan yang positif dalam mengekang penularan wabak ini. Antara amalan yang diamalkan adalah memakai pelitup muka, menjaga penjarakan sosial, tidak menghadiri majlis keramaian dan sebagainya. Bertitik tolak daripada perkara ini, amalan yang positif ini juga dapat dikaitkan dengan hasil dapatan kajian ini yang menunjukkan tahap amalan positif dalam kalangan para pelajar berasrama penuh terpilih di Malaysia adalah pada tahap yang boleh dibanggakan.

\section{Metod Kajian}

Kajian yang dijalankan ini berbentuk kajian kuantitatif yang menggunakan kaedah soal selidik bagi mendapatkan maklumat daripada responden. Reka bentuk kajian adalah kajian hirisan lintang terhadap 325 pelajar sekolah berasrama penuh Malaysia yang terpilih. Tujuan kajian ini ialah untuk mengkaji tahap pengetahuan, sikap dan amalan tentang Covid-19 di kalangan pelajar sekolah berasrama penuh. Hasil dapatan kajian ini diperoleh melalui edaran soal selidik yang diedarkan kepada responden. Soal selidik yang diedarkan kepada responden mengandungi dua bahagian iaitu Bahagian A dan Bahagian B. Bahagian A mengandungi soalan tentang demografi responden dan Bahagian B pula merupakan aspek-aspek yang dikaji. Kaedah tinjauan merupakan salah satu kaedah yang popular digunakan bagi mendapatkan informasi tentang responden.

Antara kandungan maklumat demografi adalah informasi seperti nama sekolah, tingkatan dan jantina. Skala likert digunakan supaya memudahkan responden untuk menandakan jawapan berdasarkan pengetahuan masing-masing. Pengkaji juga mendapatkan informasi dari responden melalui soal selidik atas talian dengan penggunaan platform "Google Forms". Hal ini demikian kerana, pengkaji 
menghadapi kesukaran untuk ke lokasi berikutan Perintah Kawalan Pergerakan (PKP). Bagi mendapatkan data sekunder, kajian berkenaan situasi Covid-19 di artikel- artikel dan berita turut dikaji oleh pengkaji bagi tujuan penganalisisan terhadap corak jawapan-jawapan responden. Bagi mendapatkan skor min dalam aspek yang dinilai, pengkaji menggunakan Statistical Package for Social Science (SPSS) versi 24.0. Ujian-ujian bagi penganalisisan data seperti ujian kebolehpercayaan alfa Cronbach, Ujian-t (independent sample T-test) digunakan untuk pengujian hipotesis kajian ini. Bagi melihat min, peratusan, frekuensi, dan juga sisihan piawai, statistik deskriptif digunakan.

Populasi kajian adalah daripada pelajar-pelajar tingkatan 1, 23 dan 4 iaitu Sekolah Menengah Agama Persekutuan Kajang Selangor, Sekolah Berasrama Penuh Integrasi Rawang, dan Sekolah Berasrama Penuh Integrasi Gombak, Selangor. Penentuan saiz sampel menggunakan perisian OpenEpi, bagi mendapatkan 95\% Confidence Interval dengan 5\% margin of error, seramai sekurang-kurangnya 235 orang pelajar harus terlibat dalam kajian ini. Jangka masa kajian adalah 3-6 bulan menggunakan edaran soal selidik yang telah divalidasi dan mempunyai nilai reliability Cronbach alpha 0.72 yang mengandungi 4 bahagian iaitu maklumat demografi, pengetahuan, sikap, amalan. Persampelan secara rawak mudah dilaksanakan bagi mendapatkan responden bagi memastikan kajian ini dapat dijalankan.

Kajian menggunakan borang soal selidik dan diedarkan secara bersemuka dan secara atas talian yang telah disahkan tahap kesahan dan kebolehpercayaan instrumen tersebut. Pelajar sekolah berasrama penuh yang terpilih menjadi responden. Pengkaji menentukan teknik pemprosesan data menggunakan prosedur penganalisisan data menggunakan Statistical Package for the Social Science. Terdapat dua jenis analisis yang akan dilibatkan dalam kajian ini iaitu analisis data secara statistik deskriptif dan analisis data secara inferensi melalui ujian Korelasi Pearson. Bagi menggambarkan taburan data yang diperolehi oleh pengkaji dengan lebih jelas, hasil dapatan analisis deskriptif akan memaparkan kekerapan, peratus, min dan sisihan piawai.

Maklumat dalam Jadual 1 menunjukkan responden adalah terdiri daripada tiga buah sekolah. Seramai 67 orang $(20.6 \%)$ dari SMAP Kajang, 176 orang (54.2\%) dari SBPI Rawang dan 82 orang (25.2\%) dari SBPI Gombak. Seterusnya, profil responden mengikut tingkatan menunjukkan seramai 152 orang (46.8\%) dari Tingkatan 1, 117 orang (36.0\%) dari Tingkatan 2, 10 orang (3.1\%) dari Tingkatan 3 dan 46 orang $(14.2 \%)$ dari Tingkatan 4 . Ini menunjukkan kebanyakan pelajar adalah terdiri dari kalangan Tingkatan 1. Manakala dari segi profil responden mengikut jantina menunjukkan seramai 149 orang atau 45.8 peratus adalah terdiri daripada pelajar lelaki, manakala seramai 176 orang atau 54.2 peratus lagi adalah terdiri daripada pelajar perempuan.

\section{Hasil Kajian}

Jadual 1 menunjukkan taburan demografi responden kajian dalam kalangan pelajar berasrama penuh yang terlibat dalam kajian ini.

Jadual 1: Taburan Demografi Responden

\begin{tabular}{lll}
\hline & Bilangan & Peratus \\
\hline Nama sekolah & & \\
SMAP Kajang & 67 & 20.6 \\
SBPI Rawang & 176 & 54.2 \\
SBPI Gombak & 82 & 25.2 \\
Tingkatan & & \\
TING 1 & 152 & 46.8 \\
TING 2 & 117 & 36.0 \\
TING 3 & 10 & 3.1 \\
TING 4 & 46 & 14.2 \\
Jantina & & \\
Lelaki & 149 & 45.8
\end{tabular}


Hasil analisis kebolehpercayaan alfa Cronbach bagi pengetahuan, sikap dan amalan tentang Covid-19 dalam kalangan pelajar Sekolah Berasrama Penuh dipaparkan dalam Jadual 2.

Jadual 2: Kebolehpercayaan Instrumen kajian

\begin{tabular}{lll}
\hline Pemboleh ubah & Alfa Cronbach & Bilangan Item \\
\hline Pengetahuan tentang Covid-19 & 0.338 & 7 \\
Sikap tentang Covid-19 & 0.612 & 10 \\
Amalan tentang Covid-19 & 0.759 & 13 \\
\hline
\end{tabular}

Jadual 2 di atas menunjukkan julat kebolehpercayaan bagi pengetahuan, sikap dan amalan tentang Covid-19 di kalangan pelajar Sekolah Berasrama Penuh adalah masing-masing 0.338 (7 item), 0.612 (10 item) dan 0.759 (13 item). Maka, jadual alfa Cronbach di atas menunjukkan bahawa instrumen yang digunakan mempunyai kebolehpercayaan yang baik.

Hasil taburan kenormalan data berdasarkan ujian statistik Skewness dan Kurtosis dipaparkan dalam Jadual 3.

Jadual 3: Taburan Kenormalan

\begin{tabular}{lllll}
\hline \multirow{2}{*}{ Pemboleh ubah } & Skewness & \multicolumn{3}{l}{ Kurtosis } \\
\cline { 2 - 5 } & Statistic & $\begin{array}{l}\text { Std. } \\
\text { Error }\end{array}$ & Statistic & $\begin{array}{l}\text { Std. } \\
\text { Error }\end{array}$ \\
\hline Pengetahuan tentang Covid-19 & -.507 & .135 & .203 & .270 \\
Sikap tentang Covid-19 & -.717 & .135 & .441 & .270 \\
Amalan tentang Covid-19 & -.569 & .135 & -.020 & .270 \\
\hline
\end{tabular}

Berdasarkan analisis statistik seperti dalam Jadual 3 menunjukkan pemboleh ubah kajian iaitu pengetahuan, sikap dan amalan tentang COVID-19 di kalangan pelajar Sekolah Berasrama Penuh adalah berdistribusi normal iaitu mempunyai hasil ujian pemboleh ubah di antara \pm 2 sisihan piawai. Oleh itu, data-data dalam kajian ini adalah sesuai untuk dilakukan analisis selanjutnya.

\section{Analisis Tahap Pengetahuan, Sikap dan Amalan Pelajar}

Berdasarkan Jadual 4, dapatan kajian menunjukkan tahap pengetahuan tentang Covid-19 di kalangan pelajar Sekolah Berasrama Penuh berada pada tahap yang sederhana dengan memperoleh skor antara 4 hingga 5 markah iaitu seramai 240 orang (73.8\%). Diikuti dengan seramai 45 orang (13.8\%) pada tahap tinggi dengan memperoleh skor antara 6 hingga 7 markah, dan seramai 40 orang (12.3\%) pada tahap yang rendah dengan memperoleh skor antara 2 hingga 3 markah. Secara keseluruhannya menunjukkan bahawa skor tahap pengetahuan $(\min =4.63, \mathrm{SP}=0.926)$ tentang Covid-19 dalam kalangan pelajar Sekolah Berasrama Penuh adalah berada pada tahap yang sederhana.

Jadual 4: Tahap Pengetahuan Pelajar Tentang Covid-19

\begin{tabular}{llllll}
\hline Skor & Tahap & Kekerapan & Peratus & Min & SP \\
\hline $0-1$ & Sangat rendah & 0 & 0.0 & & \\
$2-3$ & Rendah & 40 & 12.3 & & \\
$4-5$ & Sederhana & 240 & 73.8 & 4.63 & .926 \\
$6-7$ & Tinggi & 45 & 13.8 & & \\
Jumlah & & 325 & 100.0 & & \\
\hline
\end{tabular}


Jadual 5 menunjukkan skor kekerapan dan peratusan bagi setiap item pengetahuan tentang Covid-19. Berdasarkan hasil kajian ini, dapat diringkaskan bahawa pelajar mempunyai pengetahuan yang tertinggi terhadap item Covid-19 mempunyai kadar penyebaran yang tinggi sebanyak 99.1 peratus. Diikuti dengan item mencuci tangan dengan kerap menggunakan sabun dapat mencegah jangkitan Covid-19 iaitu sebanyak 93.8 peratus, item pemakaian pelitup muka pakai buang adalah salah satu kaedah pencegahan iaitu sebanyak 89.8 peratus, item Seseorang yang dijangkiti Covid-19 tidak semestinya menunjukkan simptom-simptom seperti demam iaitu sebanyak 83.7 peratus dan bagi item Penjarakan fizikal sebanyak 50cm dicadangkan untuk mencegah jangkitan Covid-19 iaitu sebanyak 52.3 peratus. Namun begitu, kebanyakan pelajar tidak mempunyai pengetahuan yang jelas terhadap item Kuman Covid-19 yang melekat pada permukaan mempunyai tempoh hayat selama 30 hari iaitu sebanyak 52.9 peratus dan item Pengambilan Vitamin C boleh mencegah Covid-19 iaitu sebanyak 55.4 peratus.

Jadual 5: Kekerapan dan Peratusan Item Pengetahuan Pelajar Tentang Covid-19

\begin{tabular}{|c|c|c|c|c|}
\hline No & Pernyataan & Tidak & $\begin{array}{l}\text { Tidak } \\
\text { Pasti }\end{array}$ & Ya \\
\hline $\mathrm{P} 1$ & Covid-19 mempunyai kadar penyebaran yang tinggi. & $\begin{array}{l}3 \\
(0.9)\end{array}$ & $\begin{array}{l}0 \\
(0.0)\end{array}$ & $\begin{array}{l}322 \\
(99.1)\end{array}$ \\
\hline $\mathrm{P} 2$ & $\begin{array}{l}\text { Seseorang yang dijangkiti Covid-19 tidak semestinya } \\
\text { menunjukkan simptom-simptom seperti demam. }\end{array}$ & $\begin{array}{l}11 \\
(3.4)\end{array}$ & $\begin{array}{l}42 \\
(12.9)\end{array}$ & $\begin{array}{l}272 \\
(83.7)\end{array}$ \\
\hline P3 & Pengambilan Vitamin C boleh mencegah Covid-19. & $\begin{array}{l}60 \\
(18.5)\end{array}$ & $\begin{array}{l}180 \\
(55.4)\end{array}$ & $\begin{array}{l}85 \\
(26.2)\end{array}$ \\
\hline $\mathrm{P} 4$ & $\begin{array}{l}\text { Kuman Covid- } 19 \text { yang melekat pada permukaan } \\
\text { mempunyai tempoh hayat selama } 30 \text { hari. }\end{array}$ & $\begin{array}{l}95 \\
(29.2)\end{array}$ & $\begin{array}{l}172 \\
(52.9)\end{array}$ & $\begin{array}{l}58 \\
(17.8)\end{array}$ \\
\hline P5 & $\begin{array}{l}\text { Penjarakan fizikal sebanyak } 50 \mathrm{~cm} \text { dicadangkan untuk } \\
\text { mencegah jangkitan Covid-19. }\end{array}$ & $\begin{array}{l}170 \\
(52.3)\end{array}$ & $\begin{array}{l}96 \\
(29.5)\end{array}$ & $\begin{array}{l}59 \\
(18.2)\end{array}$ \\
\hline P6 & $\begin{array}{l}\text { Pemakaian pelitup muka pakai buang adalah salah } \\
\text { satu kaedah pencegahan. }\end{array}$ & $\begin{array}{l}14 \\
(4.3)\end{array}$ & $\begin{array}{l}19 \\
(5.8)\end{array}$ & $\begin{array}{l}292 \\
(89.8)\end{array}$ \\
\hline P7 & $\begin{array}{l}\text { Mencuci tangan dengan kerap menggunakan sabun } \\
\text { dapat mencegah jangkitan Covid-19. }\end{array}$ & $\begin{array}{l}0 \\
(0.0)\end{array}$ & $\begin{array}{l}20 \\
(6.2)\end{array}$ & $\begin{array}{l}305 \\
(93.8)\end{array}$ \\
\hline
\end{tabular}

Jadual 6 menunjukkan skor kekerapan, peratusan, min dan sisihan piawai bagi setiap item sikap pelajar tentang Covid-19. Terdapat empat item negatif yang dinyatakan dalam bentuk negatif $(*)$ telah dikod semula sebelum dianalisis bagi memberikan gambaran tentang sikap pelajar tentang Covid-19 yang sebenar. Hasil kajian menunjukkan sembilan item mempunyai skor yang tinggi, manakala satu item lagi mempunyai skor yang sederhana. Berdasarkan dapatan kajian ini, item *S3 iaitu item rakan baik anda yang mempunyai kontak rapat dengan pesakit Covid-19 mengalami demam panas dan ke klinik untuk mendapatkan rawatan. Beliau dengan sengaja tidak menceritakan perkara sebenar kepada kakitangan kesihatan yang merawat kerana bimbang dikuarantin. Adakah anda bersetuju dengan tindakan rakan anda? mencatatkan min yang tertinggi iaitu 4.50 dan sisihan piawai 0.895. Manakala item *S5 iaitu Ahli keluarga anda di kampung disahkan mendapat jangkitan Covid-19. Adakah anda akan pulang ke kampung untuk melawat mereka yang sakit? pula mencatatkan min yang terendah iaitu 3.44 dan sisihan piawai 1.453. Secara keseluruhannya menunjukkan bahawa skor tahap sikap tentang Covid-19 $(\min =4.17, \mathrm{SP}=0.462)$ dalam kalangan pelajar Sekolah Berasrama Penuh adalah berada pada tahap yang tinggi.

Jadual 6: Tahap Sikap Pelajar Tentang Covid-19

\begin{tabular}{lllllllll}
\hline No & Pernyataan & STS & TS & KS & S & SS & Min & SP \\
\hline S1 & Sekiranya anda diminta untuk & & & & & & & \\
& $\begin{array}{l}\text { menjalani saringan Covid-19 } \\
\text { kerana rakan di sekolah yang } \\
\text { sama telah disahkan positif }\end{array}$ & 0 & 6 & 20 & 113 & 186 & 4.47 & .696 \\
& & & & & & & &
\end{tabular}


Covid-19, anda akan terus ke

hospital/klinik kesihatan

berdekatan.

*S2 Adakah anda bersetuju bahawa penggunaan pelitup muka pakai buang adalah suatu pembaziran?

$\begin{array}{lllllll}122 & 127 & 56 & 18 & 2 & 4.07 & .906 \\ (37.5) & (39.1) & (17.2) & (5.5) & (0.6) & & \end{array}$

*S3 Rakan baik anda yang mempunyai kontak rapat dengan pesakit Covid-19 mengalami demam panas dan ke klinik untuk mendapatkan rawatan. Beliau dengan sengaja tidak menceritakan perkara sebenar kepada kakitangan kesihatan yang merawat kerana bimbang dikuarantin. Adakah anda bersetuju dengan tindakan rakan anda?

S4 Keluarga anda ingin melawat anda di sekolah, akan tetapi, pihak sekolah tidak membenarkan lawatan dari ahli keluarga dalam tempoh ini. Adakah anda bersetuju dengan larangan ini?

*S5 Ahli keluarga anda di kampung disahkan mendapat jangkitan Covid-19. Adakah anda akan pulang ke kampung untuk melawat mereka yang sakit?

*S6 Sekiranya saya tidak mempunyai gejala demam, saya tidak perlu memakai pelitup muka di tempat awam.

S7 Pencucian tangan dengan sabun adalah suatu perkara yang mudah untuk dilakukan.

$\begin{array}{lllllll}217 & 77 & 17 & 4 & 10 & 4.50 & .895 \\ (66.8) & (23.7) & (5.2) & (1.2) & (3.1) & & \end{array}$

$\begin{array}{lllllll}8 & 13 & 55 & 137 & 112 & 4.02 & .947 \\ (2.5) & (4.0) & (16.9) & (42.2) & (34.5) & & \end{array}$

$\begin{array}{lllllll}104 & 82 & 45 & 42 & 52 & 3.44 & 1.453 \\ (32.0) & (25.2) & (13.8) & (12.9) & (16.0) & & \end{array}$

$\begin{array}{lllllll}132 & 115 & 48 & 19 & 11 & 4.04 & 1.046 \\ (40.6) & (35.4) & (14.8) & (5.8) & (3.4) & & \end{array}$

$\begin{array}{lllllll}2 & 11 & 22 & 86 & 204 & 4.47 & .815\end{array}$

S8 Jika diarahkan penggunaan tirai pada katil-katil anda untuk mencegah Covid-19, anda akan tidur dengan selesa.

S9 Anda berasa selamat jika semua orang mematuhi garis panduan pencegahan Covid-19.

$\begin{array}{lllll}17 & 20 & 69 & 99 & 120\end{array}$

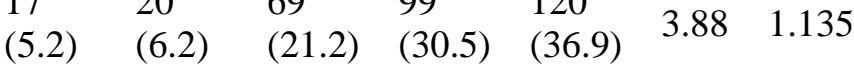

$\begin{array}{lllllll}4 & 4 & 29 & 85 & 203 & 4.47 & .807\end{array}$

S10 Anda amat takut akan jangkitan Covid-19.

$\begin{array}{lllll}3 & 6 & 51 & 77 & 188\end{array}$
$\begin{array}{lllllll}(0.9) & (1.8) & (15.7) & (23.7) & (57.8) & 4.36 & .876\end{array}$ Min Keseluruhan $4.17 \quad .462$

Nota: Tahap: Rendah $=1.00-2.33$, Sederhana $=2.34-3.66$, Tinggi $=3.67-5.00$

*Pernyataan negatif

Jadual 7 menunjukkan skor kekerapan, peratusan, min dan sisihan piawai bagi setiap item amalan pelajar tentang Covid-19. Terdapat tiga item negatif yang dinyatakan dalam bentuk negatif $(*)$ telah dikod semula sebelum di analisis bagi memberikan gambaran tentang amalan pelajar tentang Covid-19 yang sebenar. Hasil kajian menunjukkan dua belas item mempunyai skor yang tinggi, manakala satu item lagi mempunyai skor yang sederhana. Berdasarkan dapatan kajian ini, item A3 iaitu item Apabila 
DOI: https://doi.org/10.47405/mjssh.v6i12.1202

solat, anda menggunakan sejadah anda sendiri mencatatkan min yang tertinggi iaitu 4.72 dan sisihan piawai 0.564. Manakala item *A4_ii iaitu item Apabila anda bersin, selalunya anda menutup mulut dan hidung anda menggunakan tangan pula mencatatkan min yang terendah iaitu 3.57 dan sisihan piawai 1.553. Secara keseluruhannya menunjukkan bahawa skor tahap amalan tentang Covid-19 (min $=4.31, \mathrm{SP}=0.508$ ) dalam kalangan pelajar Sekolah Berasrama Penuh adalah berada pada tahap yang tinggi.

Jadual 7: Tahap Amalan Pelajar Tentang Covid-19

\begin{tabular}{|c|c|c|c|c|c|c|c|c|}
\hline No & Pernyataan & STS & TS & KS & $\mathbf{S}$ & SS & Min & SP \\
\hline A1 & $\begin{array}{l}\text { Cecair pencuci tangan (hand } \\
\text { sanitizer) ada dengan anda pada } \\
\text { setiap masa. }\end{array}$ & $\begin{array}{l}2 \\
(0.6)\end{array}$ & $\begin{array}{l}11 \\
(3.4)\end{array}$ & $\begin{array}{l}55 \\
(16.9)\end{array}$ & $\begin{array}{l}103 \\
(31.7)\end{array}$ & $\begin{array}{l}154 \\
(47.4)\end{array}$ & 4.22 & .888 \\
\hline A2 & $\begin{array}{l}\text { Anda menggunakan pelitup } \\
\text { muka setiap hari di sekolah. }\end{array}$ & $\begin{array}{l}7 \\
(2.2)\end{array}$ & $\begin{array}{l}16 \\
(4.9)\end{array}$ & $\begin{array}{l}49 \\
(15.1)\end{array}$ & $\begin{array}{l}65 \\
(20.0)\end{array}$ & $\begin{array}{l}188 \\
(57.8)\end{array}$ & 4.26 & 1.026 \\
\hline A3 & $\begin{array}{l}\text { Apabila solat, anda } \\
\text { menggunakan sejadah anda } \\
\text { sendiri. }\end{array}$ & $\begin{array}{l}0 \\
(0.0)\end{array}$ & $\begin{array}{l}0 \\
(0.0)\end{array}$ & $\begin{array}{l}19 \\
(5.8)\end{array}$ & $\begin{array}{l}52 \\
(16.0)\end{array}$ & $\begin{array}{l}254 \\
(78.2)\end{array}$ & 4.72 & .564 \\
\hline A4 & $\begin{array}{l}\text { Apabila anda bersin, selalunya } \\
\text { anda menutup mulut dan hidung } \\
\text { anda menggunakan: }\end{array}$ & & & & & & & \\
\hline i. & Tisu & $\begin{array}{l}5 \\
(1.5)\end{array}$ & $\begin{array}{l}5 \\
(1.5)\end{array}$ & $\begin{array}{l}42 \\
(12.9)\end{array}$ & $\begin{array}{l}53 \\
(16.3)\end{array}$ & $\begin{array}{l}220 \\
(67.7)\end{array}$ & 4.47 & .887 \\
\hline$*_{\mathrm{ii}}$ & Tangan & $\begin{array}{l}141 \\
(43.4)\end{array}$ & $\begin{array}{l}54 \\
(16.6)\end{array}$ & $\begin{array}{l}40 \\
(12.3)\end{array}$ & $\begin{array}{l}30 \\
(9.2)\end{array}$ & $\begin{array}{l}60 \\
(18.5)\end{array}$ & 3.57 & 1.553 \\
\hline iii. & Lengan Baju & $\begin{array}{l}22 \\
(6.8)\end{array}$ & $\begin{array}{l}14 \\
(4.3)\end{array}$ & $\begin{array}{l}32 \\
(9.8)\end{array}$ & $\begin{array}{l}75 \\
(23.1)\end{array}$ & $\begin{array}{l}182 \\
(56.0)\end{array}$ & 4.17 & 1.189 \\
\hline$*_{\mathrm{iv}}$ & Tidak Tutup & $\begin{array}{l}232 \\
(71.4)\end{array}$ & $\begin{array}{l}63 \\
(19.4)\end{array}$ & $\begin{array}{l}17 \\
(5.2)\end{array}$ & $\begin{array}{l}2 \\
(0.6)\end{array}$ & $\begin{array}{l}11 \\
(3.4)\end{array}$ & 4.55 & .893 \\
\hline A5 & $\begin{array}{l}\text { Sejadah yang anda gunakan } \\
\text { tidak bercampur dengan sejadah } \\
\text { rakan-rakan lain. }\end{array}$ & $\begin{array}{l}7 \\
(2.2)\end{array}$ & $\begin{array}{l}6 \\
(1.8)\end{array}$ & $\begin{array}{l}39 \\
(12.0)\end{array}$ & $\begin{array}{l}61 \\
(18.8)\end{array}$ & $\begin{array}{l}212 \\
(65.2)\end{array}$ & 4.43 & .926 \\
\hline$* \mathrm{~A} 6$ & $\begin{array}{l}\text { Apabila berjumpa dengan rakan- } \\
\text { rakan apabila anda pulang dari } \\
\text { kampung, anda bersalaman } \\
\text { dengan mereka. }\end{array}$ & $\begin{array}{l}166 \\
(51.1)\end{array}$ & $\begin{array}{l}83 \\
(25.5)\end{array}$ & $\begin{array}{l}49 \\
(15.1)\end{array}$ & $\begin{array}{l}22 \\
(6.8)\end{array}$ & $\begin{array}{l}5 \\
(1.5)\end{array}$ & 4.18 & 1.021 \\
\hline A7 & $\begin{array}{l}\text { Anda tidak berkongsi berus gigi } \\
\text { dengan rakan lain. }\end{array}$ & $\begin{array}{l}13 \\
(4.0)\end{array}$ & $\begin{array}{l}1 \\
(0.3)\end{array}$ & $\begin{array}{l}15 \\
(4.6)\end{array}$ & $\begin{array}{l}44 \\
(13.5)\end{array}$ & $\begin{array}{l}252 \\
(77.5)\end{array}$ & 4.60 & .913 \\
\hline A8 & $\begin{array}{l}\text { Anda tidak berkongsi pakaian } \\
\text { dengan rakan lain. }\end{array}$ & $\begin{array}{l}11 \\
(3.4)\end{array}$ & $\begin{array}{l}5 \\
(1.5)\end{array}$ & $\begin{array}{l}31 \\
(9.5)\end{array}$ & $\begin{array}{l}61 \\
(18.8)\end{array}$ & $\begin{array}{l}217 \\
(66.8)\end{array}$ & 4.44 & .969 \\
\hline A9 & $\begin{array}{l}\text { Anda kerap mencuci tangan } \\
\text { dengan menggunakan sabun. }\end{array}$ & $\begin{array}{l}1 \\
(0.3)\end{array}$ & $\begin{array}{l}7 \\
(2.2)\end{array}$ & $\begin{array}{l}41 \\
(12.6)\end{array}$ & $\begin{array}{l}95 \\
(29.2)\end{array}$ & $\begin{array}{l}181 \\
(55.7)\end{array}$ & 4.38 & .810 \\
\hline A10 & $\begin{array}{l}\text { Anda tidak berkongsi makanan } \\
\text { dengan rakan anda. }\end{array}$ & $\begin{array}{l}8 \\
(2.5)\end{array}$ & $\begin{array}{l}17 \\
(5.2)\end{array}$ & $\begin{array}{l}78 \\
(24.0)\end{array}$ & $\begin{array}{l}65 \\
(20.0)\end{array}$ & $\begin{array}{l}157 \\
(48.3)\end{array}$ & 4.06 & 1.074 \\
\hline & Min Keseluruhan & & & & & & 4.31 & .508 \\
\hline
\end{tabular}

Nota: Tahap: Rendah $=1.00-2.33$, Sederhana $=2.34-3.66$, Tinggi $=3.67-5.00$

* Pernyataan negatif

Jadual 8: Keputusan Ujian Hipotesis

\begin{tabular}{lllll}
\hline & & Pengetahuan & Sikap & Amalan \\
\hline Pengetahuan & Pearson Correlation & 1 & .033 & $-.196^{* *}$ \\
& Sig. (2-tailed) & & .554 & .000 \\
\multirow{5}{*}{ Sikap } & $\mathrm{N}$ & 325 & 325 & 325 \\
& Pearson Correlation & .033 & 1 & $.389^{* *}$ \\
& Sig. (2-tailed) & .554 & & .000 \\
\hline
\end{tabular}


DOI: https://doi.org/10.47405/mjssh.v6i12.1202

\begin{tabular}{lllll}
\hline \multirow{3}{*}{ Amalan } & $\mathrm{N}$ & 325 & 325 & 325 \\
& Pearson Correlation & $-.196^{* *}$ & $.389^{* * *}$ & 1 \\
& Sig. (2-tailed) & .000 & .000 & \\
& $\mathrm{~N}$ & 325 & 325 & 325 \\
\hline
\end{tabular}

Nota: $* *$. Correlation is significant at the 0.01 level (2-tailed).

Dalam Jadual 8 di atas menunjukkan keputusan pengujian hipotesis kesan langsung menghasilkan tiga dapatan penting. Hubungan di antara dua pemboleh ubah yang signifikan diukur apabila aras signifikan bersamaan dengan 0.05. Pertama, pengetahuan $[\mathrm{r}=0.033, \mathrm{p}>0.05]$ tidak mempunyai hubungan yang signifikan dengan sikap tentang Covid-19 di kalangan pelajar Sekolah Berasrama Penuh. Dengan itu, Ho4 adalah diterima. Kedua, pengetahuan $[\mathrm{r}=0.196, \mathrm{p}<0.05]$ mempunyai hubungan dengan amalan tentang Covid-19 di kalangan pelajar Sekolah Berasrama Penuh. Dengan itu, Ho5 adalah ditolak. Ketiga, sikap $[\mathrm{r}=0.389, \mathrm{p}>0.05]$ tidak mempunyai hubungan yang signifikan dengan amalan tentang Covid-19 di kalangan pelajar Sekolah Berasrama Penuh. Dengan itu, Ho6 adalah ditolak.

\section{Perbincangan Kajian}

Bahagian perbincangan ini akan mengupas dan membincangkan berkaitan keputusan oleh dapatan kajian yang telah diperoleh oleh pengkaji. Dapatan kajian mendapati terdapat perbezaan yang signifikan terhadap tahap pengetahuan pelajar Sekolah Berasrama Penuh di Malaysia. Kajian ini bertujuan bagi mengenal pasti tahap pengetahuan, sikap dan amalan tentang Covid-19 di kalangan pelajar Sekolah Berasrama Penuh. Selain itu, objektif kajian ini juga bagi mengenal pasti hubungan antara pengetahuan, sikap dan amalan tentang Covid-19 di kalangan pelajar Sekolah Berasrama Penuh.

\section{Tahap Pengetahuan, Sikap dan Amalan Pelajar}

Berdasarkan dapatan kajian dalam bab empat, dapat dirumuskan bahawa tahap pengetahuan majoriti pelajar adalah berada pada tahap sederhana iaitu sebanyak $73.8 \%$ skor antara empat hingga lima markah diikuti seramai $13.8 \%$ di tahap tinggi dan pada tahap rendah adalah seramai $12.3 \%$. Menurut kajian oleh Jessie (2020), tahap pengetahuan berkenaan COVID-19 dalam kalangan wanita di Uttar Pradesh dan Bihar, India menunjukkan tahap yang tinggi dengan peratusan sebanyak $70 \%$ berbanding dengan tahap pengetahuan lelaki iaitu dengan 30\% sahaja. Hal ini dapat dilihat juga dengan kajian yang dijalankan oleh Muhammad (2020) yang berpendapat hasil kajiannya di sebuah sekolah di Jordan mendapati $81.3 \%$ pelajar perempuan mempunyai tahap pengetahuan yang tinggi. Hal ini demikian kerana, para pelajar perempuan tersebut memperoleh informasi berkenaan Covid-19 di media sosial dan di sekolah juga. Tahap amalan para pelajar perempuan juga menunjukkan tahap yang tinggi berbanding pelajar lelaki yang berada pada tahap sederhana (Muhammad, 2020).

Selain itu, kajian ini turut memfokuskan kepada tahap sikap pelajar berkenaan Covid-19 ini. Hasil kajian mendapati bahawa skor tahap sikap tentang COVID-19 adalah pada tahap yang tinggi dengan $\mathrm{SP}=0.462)$. Perkara ini dapat dikaitkan dengan kajian oleh Ressa (2020) yang menyatakan bahawa sebanyak $62.3 \%$ responden menunjukkan sikap yang positif terhadap pengekangan wabak ini. Seramai 90\% pelajar di sebuah kolej perubatan di Makkah, Saudi Arabia menunjukkan sikap yang positif terhadap usaha dalam mengekang penularan wabak Covid-19.

Seterusnya, dapatan kajian juga mendapati secara keseluruhannya skor tahap amalan tentang Covid 19 dalam kalangan pelajar Sekolah Berasrama Penuh adalah berada pada tahap yang tinggi. Kajian yang dijalankan Muhammed Al Hanawi et al. (2020) mendapati tahap amalan yang diamalkan oleh pelajar di Arab Saudi tidak menunjukkan perbezaan yang signifikan. Hal ini demikian kerana, pelajar lelaki dan perempuan mengamalkan tahap amalan yang efektif bagi mengekang penularan wabak ini. Ini juga dapat dilihat dari hasil kajian oleh Muhammad (2020) yang mendapati tahap amalan yang diamalkan oleh para pelajar di sebuah sekolah di Indonesia menunjukkan tidak terdapat perbezaan yang signifikan dari sudut amalan dan sikap. Hal ini demikian kerana, para pelajar tidak kira lelaki 
atau perempuan mendapat informasi berkenaan kepentingan menjaga kebersihan di media sosial dan media sosial dan melalui Kementerian Kesihatan di negara mereka.

\section{Hubungan antara Pengetahuan, Sikap dan Amalan}

Kajian ini juga bertujuan untuk mengenal pasti hubungan antara pengetahuan, sikap dan amalan tentang Covid-19 di kalangan pelajar Sekolah Berasrama Penuh. Hasil analisis korelasi mendapati pengetahuan tidak mempunyai hubungan yang signifikan dengan sikap tentang COVID-19 di kalangan pelajar Sekolah Berasrama Penuh. Kedua, pengetahuan mempunyai hubungan yang signifikan yang negatif dengan amalan tentang Covid-19 di kalangan pelajar Sekolah Berasrama Penuh. Ketiga, sikap mempunyai hubungan yang signifikan dengan amalan tentang Covid-19 di kalangan pelajar Sekolah Berasrama Penuh. Hasil dapatan ini selari dengan kajian Muhammed Al Hanawi et al. (2020) menyatakan bahawa terdapat hubungan kolerasi yang negatif antara pengetahuan dan amalan dalam kalangan pelajar.

\section{Kesimpulan}

Secara keseluruhannya, melalui kajian yang dijalankan, hasil analisis deskriptif menunjukkan bahawa skor tahap pengetahuan tentang Covid-19 dalam kalangan pelajar Sekolah Berasrama Penuh adalah berada pada tahap yang sederhana. Selain itu, tahap sikap para pelajar berasrama penuh secara keseluruhannya menunjukkan bahawa skor tahap sikap tentang Covid-19 dalam kalangan pelajar Sekolah Berasrama Penuh adalah berada pada tahap yang tinggi. Seterusnya, tahap amalan juga menunjukkan tahap yang tinggi. Hasil analisis korelasi pula mendapati tidak terdapat hubungan antara pengetahuan dengan sikap tentang Covid-19 di kalangan pelajar Sekolah Berasrama Penuh. Selain daripada itu, tidak terdapat hubungan antara pengetahuan dengan amalan tentang Covid-19 di kalangan pelajar Sekolah Berasrama Penuh dan tidak terdapat hubungan antara sikap dengan amalan tentang Covid-19 di kalangan pelajar Sekolah Berasrama Penuh. Pengkaji mencadangkan agar kajiankajian berkaitan tahap pengetahuan, sikap dan amalan pelajar berkenaan Covid-19 akan dilakukan secara meluas lagi bukan sahaja di sekolah-sekolah berasrama penuh malah di sekolah-sekolah harian juga. Hal ini demikian kerana, kajian-kajian yang akan dilakukan sedikit sebanyak akan memberi pendedahan dan memberi impak yang besar kepada masyarakat juga tentang Covid-19 yang sedang melanda di Malaysia khususnya. Pengkaji juga ingin mencadangkan agar kajian berkenaan tahap pengetahuan, sikap dan amalan pelajar di peringkat pengajian tinggi juga dijalankan agar para siswa dan siswi dapat pengetahuan yang lebih meluas dan sentiasa mengambil langkah-langkah pencegahan yang sewajarnya sebelum pengajian di pusat pengajian dapat diteruskan.

\section{Rujukan}

Asuka, H., Xinhua, M., Yi, Z., Norihito, K., Zheng, W., Mikiko, U., Tatsuya, T., \& Yu, S. T. (2020). Knowledge, attitudes, and practices toward covid-19 among university students in Japan and associated factors: an online cross-sectional survey. PLOS ONE, 15(12), 244-350.

Aisha, A., Michael, A. J., Jansirani, N., \& Rasha, A. B. (2021). Knowledge, attitude, and practice of nursing students towards covid-19 pandemic in Oman. International Journal of Nursing Education, 13(1), 23-29.

Al-Hazmi, A., Gosadi, I., Somily, A., Alsubaie, S., \& Saeed, A. B. (2018). Knowledge, attitude and practice of secondary schools and university students toward Middle East Respiratory Syndrome epidemic in Saudi Arabia: A cross-sectional study. Saudi Journal of Biological Sciences, 25(3), 572-577.

Azlan, A. A., Hamzah, M. R., Sern, T. J., Ayub, S. H., \& Mohamad, E. (2020). Public knowledge, attitudes and practices towards COVID-19: A cross-sectional study in Malaysia. PloS One, 15(5), 233- 668.

Al-Hanawi, M. K., Angawi, K., Alshareef, N., Qattan, A., Helmy, H. Z., Abudawood, Y., Alqurashi, M., Kattan, W. M., Kadasah, N. A., Chirwa, G. C., \& Alsharqi, O. (2020). Knowledge, attitude 
and practice toward covid-19 among the public in the kingdom of Saudi Arabia: A CrossSectional Study. Frontiers In Public Health, 8(1), 217- 221.

Bhawna, S., \& Reddy, P. B. (2020). Assessment of KAP (knowledge, attitude, and practice) of university students towards prevention of covid-19. International Journal of Biological Innovations, 2(2), 117-125.

Chen, J., He, H., Cheng, W., Liu, Y., Sun, Z., Chai, C., Kong, Q., Sun, W., Zhang, J., Guo, S., Shi, X., Wang, J., Chen, E., \& Chen, Z. (2020). Potential transmission of SARS-CoV-2 on a flight from Singapore to Hangzhou, China: An epidemiological investigation. Travel Medicine And Infectious Disease, 36(1), 101- 816.

Gebretsadik, D., Gebremichael, S., \& Belete, M. A. (2021). Knowledge, attitude and practice toward covid-19 pandemic among population visiting dessie health center for covid-19 screening, Northeast Ethiopia. National Library of Medicine, 14(1), 905-915.

Hamed, M., Alzoubi, A., M. A., Nedal, A., \& Amin, Aqel. (2020). COVID-19- knowledge, attitude, and practice among medical and non-medical university students in Jordan. Journal of Pure and Applied Microbiology, 1(2), 22-27.

Jaafar, M. H., \& Azzeri, A. (2020). Winning the war against covid-19 in Malaysia: an achievable goal?. Malaysian Journal of Public Health Medicine, 20(1), 148-149.

Lee, M., Kang, B. A., \& You, M. (2021). Knowledge, attitudes, and practices (KAP) toward COVID19: a cross-sectional study in South Korea. BMC Public Health, 21(1), 280-295.

Minjung, L., Bee, A. K., \&Myoungsoon, Y. (2020). Knowledge, attitudes, and practices (KAP) toward COVID-19: a cross-sectional study in South Korea. BMC Public Health, 21(1), 285-295.

Muhammad, I., Zuriani, H., \& Nur. H. (2020). Persepsi pelajar Kolej Universiti Islam Melaka terhadap pelaksanaan pembelajaran secara atas talian dalam era pandemik covid-19. Jurnal Kesidang, 5 (1), 88-99.

Nimetcan, M., Al-abed, Ali., Al-Abed, M. E. G., Asita, E., Egemen, U., Salih, M. (2020). Knowledge, attitudes and practices regarding COVID-19 among the Turkish and Malaysian general populations during lockdown: A cross-sectional online survey Ethiop. J. Health Dev, 34(4),10-21.

Nawar, S. K., Dhafer, B. A. Y., \& Ruqaya, S. T. (2020). COVID-19 knowledge, attitude and practice among medical undergraduate students in Baghdad city. Journal of Biosciences, 14(1), 41794186.

Puwaneswarry, M., \& Nathratul, A. Z., \& Gaaitheri, K., Lim, K. Q. \& Wong, Y. H., \& Tang, S. L., \& Ng, C., G. (2020). Development of knowledge, attitudes, and practices (KAP) towards COVID19 pandemic in Malaysia. Medicine \& Health, 15(2), 262-275.

Ressa, A. U., Ria, E. M., \& Martini. (2020). Pengetahuan, sikap dan keterampilan masyarakat dalam pencegahan covid-19 di provinsi dki Jakarta. Jurnal Kesehatan Holistic, 4(2), 2621-8704.

Rajaratnam, A., Baby, N. M., Kuruvilla, T. S., Machado, S. (2014). Diagnosis of asymptomatic bacteriuria and associated risk factors among pregnant women in mangalore, karnataka, India. $J$ Clin Diagn, 8(1), 8537- 4842.

Sigit Sanyata. (2012). Teori dan aplikasi pendekatan behavioristik dalam konseling. Jurnal Paradigma, 14(1), 23-31.

Sukesih, U., Setia, B., Dian, N., \& A, Sari. (2020). Pengetahuan dan sikap mahasiswa kesehatan tentang pencegahan covid-19 di Indonesia. Jurnal Ilmu Keperawatan dan Kebidanan, 11(2), 258 $-264$.

Umeizudike, K. A., Isiekwe, I. G., Fadeju, A. D., Akinboboye, B. O., \& Aladenika, E. T. (2021). Nigerian undergraduate dental students' knowledge, perception, and attitude to COVID-19 and infection control practices. Journal of Dental Education, 85(2), 187-196. 